\title{
Influence of Abiotic Factors on the Shootfly (Atherigona pulla Wiede) Infestation
}

\author{
Kamal Kartik Kenny Kundra, M. K. Chakravarty and Alka Kumari* \\ Department of Agril. Entomology, Birsa Agricultural University, Kanke \\ Ranchi-834006 (Jharkhand), India \\ *Corresponding author
}

\section{A B S T R A C T}

Ke y w o r d s
Little millet,
Shootfly,
Atherigona soccata,
Weather parameter,
Abiotic factor
Article Info
Accepted:
30 May 2020
Available Online:
10 June 2020

Keywords

Little millet,

Shootfly,

Atherigona soccata,

Abiotic factor

Article Info

Accepted:

Available Online:

10 June 2020
A field trial was conducted at little millet research plot of Birsa Agricultural University, Kanke, Ranchi during Kharif season of 2017, in order to find the effect of abiotic factor ofimportant abiotic factors on the incidence of shoot fly in little millet var BG1.Maximum infestation of Atherigona pulla was observed in the $3^{\text {rd }}$ week after germination (i.e., $3^{\text {rd }}$ week of July)when the maximum and minimum temperature, $\mathrm{RH}$ at $7 \mathrm{AM}$ and at $2 \mathrm{PM}$ and rainfall was 29.5,21.0, 84.6 per cent, 71.6 per cent and $56.1 \mathrm{~mm}$, respectively and lowest dead heart was observed at one week after germination. Maximum temperature $(r=0.649854), \mathrm{RH}$ at 7 AM ( $\mathrm{r}=$ $0.17913)$ and at RH 2 PM $(\mathrm{r}=-0.58671)$ had negative correlation with dead hearts caused by A. pulla.

\section{Introduction}

Little millet is scientifically known as Panicum sumatrense (miliare) (Rolk Roem and Schult). Millets are one of the oldest foods known to humans and its grain was possibly the first used for domestic purpose. Millets are important crops in the world agriculture economics, used both as for food for human and feed for animals. Due to capability of withstanding draught conditions, it is a good choice for those areas where rainfall is meagre or very little to moderate in India. Total millet production in 2010 in India was 10.94 MT with the productivity of 9513 hectogram per hectare $(\mathrm{FAO}, 2011)^{[6]}$. In Jharkhand, it is known by Gundli. Before the division of Bihar, Gundli was a popular crop in southern part of Bihar (now Jharkhand), particularly among the rural and tribal people. In Jharkhand, little millet crop is grown in Kharif season. Due to its high nutritional values, now-a-days, this crop is a good choice among the urban and elite group of people. It is a short duration crop, takes about 65 to 75 days, depending on the variety cultivated. Often, 
little millet serves as a food and contributes to the nutritional security of small and marginal farmers who live in remote areas. According to Kulkarni et al., 1992 ${ }^{[10]}$, Hadimani and Malleshi, 1993 ${ }^{[7]}$ and Itagi, 2003 ${ }^{[8]}$ the grain compares well with other cereals. It has a fair source of protein (7.70 to $16.50 \%)$, Fat (2.45 to $9.04 \%)$, Carbohydrate (62.50 to $76.30 \%$ ) and is an excellent source of dietary fiber (15.90 to 18.10) with good amount of soluble (3.15 to 5.70) and insoluble (10.20 to 14.95 $\%)$ fraction. Shootfly is a dominant pest among several pests attacking the little millet (Jotwani et. al., 1969) ${ }^{[9]}$. The shootfly ranks first among the insect pests that attack little millet and often resulting in per cent loss to the crop (Anonymous, 1991) ${ }^{[1]}$. Peak period of activity of shootfly species, viz., Atherigona socaata Rondani and A. naqvii Steyskal was determined when 20 and 14 different maize germplasm were sown during spring 1981 and 1983, the first sowing commencing from $18^{\text {th }} / 17^{\text {th }}$ February followed by seven sowing at weekly intervals, viz., $25^{\text {th }} / 24^{\text {th }}$ February, $4^{\text {th }} / 3^{\text {rd }}$ March, $11^{\text {th }} / 10^{\text {th }}$ March, $18^{\text {th }} / 19^{\text {th }}$ March, 25 ${ }^{\text {th }} / 24^{\text {th }}$ March, $1^{\text {st }}$ April $/ 31^{\text {st }}$ March and $8^{\text {th }} / 7^{\text {th }}$ April, respectively. On the basis of number of eggs laid by $A$. soccata on the foliage and stalk by $A$. naqvii in the cracks and crevices in the soil around the seedlings as also dead hearts produced, their peak period of activity was observed in crop sown from $3^{\text {rd }}$ week of February to $1^{\text {st }}$ week of March. $A$. naqvii laid more number of eggs on/in soil as against $A$. soccata on leaves and stalk of the plant. Regardless of sowing dates, EVA 605 received less number of eggs and low percentage of deadhearts in both the years (Marwaha, 1984) ${ }^{[12]}$.

The temperature range between $25^{\circ}$ to $30^{\circ} \mathrm{C}$ and relative humidity between 60 to 90 per cent were worked out to bethe optimum conditions for the development of shootfly. However, the best combinations were found to be 30 and 90 per cent R. H (Doharey et al.,
1977) ${ }^{[5]}$.Mahapatra and Dhir (1994) $)^{[11]}$ reported that the attack of shootfly is more severe in case of late sowing as compared to early sown (before $21^{\text {st }}$ July) of little millet. The grain yield response of rabi sorghum to sowing date was in favour of early sowing $\left(15^{\text {th }}\right.$ September to $15^{\text {th }}$ October) rather than late sowing (beyond $1^{\text {st }}$ November) (Chorge and Ramshe $1990^{[2]}$ ). Dahatonde and Moghe $(1991)^{[4]}$ who recorded a grain yield level of $1.22 \mathrm{t} / \mathrm{ha}\left(27^{\text {th }}\right.$ September, sowing) compared to $0.81 \mathrm{t} / \mathrm{ha}\left(27^{\text {th }}\right.$ October sowing) with no significant effect of sowing date on fodder yield or test weight. Time of sowing has been found to be of great significance in reducing the level of damage by shootfly in the monsoon season. This observation is generally related to the fact that shootfly populations remain very low during the hot and dry season and the beginning of the following rainy season (Starks, 1970) ${ }^{[15]}$.

\section{Materials and Methods}

\section{Experimental site}

Afield trials were carried out at Small Millets Research plots of Ranchi Agriculture College under Birsa Agricultural University, Kanke, Ranchi, during kharif, 2017-2018 situated at the $23^{\circ} 17^{\prime}$ North latitude and $85^{\circ} 19^{\prime}$ East longitude with an altitude of 625 meters above mean sea levelhaving sub-tropical climate. The location fall under Agro-climate zone of Central and Western Plateau Zone with an average annual rainfall of $1400 \mathrm{~mm}$ per year.Weekly meteorological data on temperature, rainfall and relative humidity were obtained from the meteorological observatory records maintained in the Department of Agricultural Physics and Meteorology, Birsa Agricultural University, Ranchi.

Under the present experiment, the shootfly incidence was recorded on the variety BG1. 
For that ten plants were selected in all the three replications in the control plots under the insecticidal experiment. The egg count of shootfly was recorded at weekly intervals starting from fourteen days after germination and continued up to eight weeks after germination of plants. Weekly meteorological data on temperature, humidity and rainfall were obtained from the Department of Agricultural Physics and Meteorology, Birsa Agricultural University, Kanke, Ranchi. The data collected on temperature, humidity and rainfall from $27^{\text {th }}$ standard week, 2017 to $34^{\text {th }}$ standard week, and 2017 were finally correlated with shootfly egg count and its incidence as well by using the formula given below:

\section{Correlation coefficient $(\mathrm{r})=\sum \mathrm{xy}-\left(\sum \mathrm{x}\right)\left(\sum \mathrm{y}\right) / \mathrm{n}$}

\section{Results and Discussion}

To estimate the nature and degree of relationship between egg count per plant and dead heart percentage with weather variable viz., temperature (maximum and minimum), relative humidity (morning and afternoon) and the rainfall, correlation studies have been done. The results obtained on the correlation between infestation due to shootfly and weather parameters are given here under (Table-1 and Fig. 1).

\section{Number of eggs}

The mean egg count of $A$. pulla Wiede was ranged from 0.25 to 0.63 eggs per plant from 7 to 56 days after germination. The mean egg count was $0.78 \mathrm{egg}$ per plant while the maximum egg count was observed at three week after emergence ( $3{ }^{\text {rd }}$ week of July) when the weather parameters like maximum and minimum temperatures, relative humidity at 7 $\mathrm{AM}$ and $2 \mathrm{PM}$ and rainfall was $29.5^{\circ} \mathrm{C}, 21.0$ ${ }^{0} \mathrm{C}, 84.6$ per cent, 71.6 per cent, and $56.1 \mathrm{~mm}$, respectively. The correlation analysis indicated that maximum temperature $(\mathrm{r}=$ $0.45634)$, RH 7AM ( $\mathrm{r}=0.038225)$, and $\mathrm{RH}$ 2PM ( $\mathrm{r}=0.621393)$ negatively influenced the count of $A$. pulla meaning there by an increase in maximum temperature and relative humidity (7AM) resulted in falling in egg count of A. pulla. However, the RH at 2 PM had a significant high positive correlation with egg count (0.0621393). Except for these factors, there was no influence of other weather parameters on the egg count of $A$. pulla infesting little millet (Table no. -2).

Fig.1

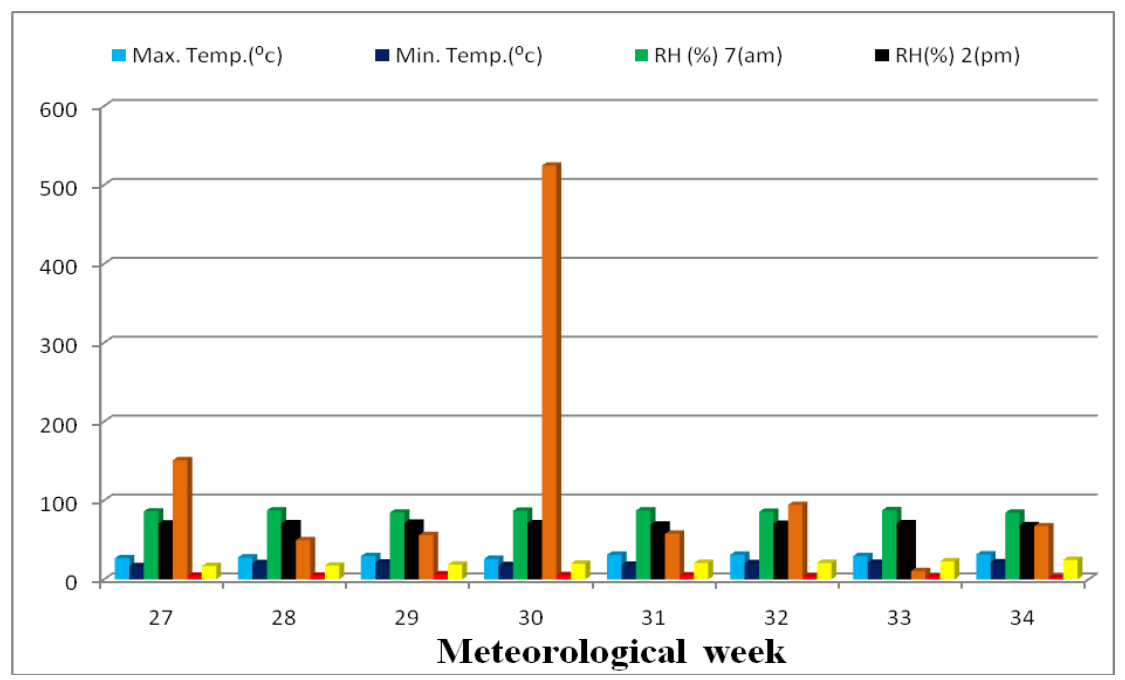


Table.1 Weekly weather condition during the experimental period

\begin{tabular}{|c|c|c|c|c|c|c|}
\hline \multirow{2}{*}{$\begin{array}{c}\text { Meteorological } \\
\text { Weeks. } \\
2017\end{array}$} & \multirow[t]{2}{*}{ Period } & \multicolumn{2}{|c|}{ Temperature $\left({ }^{\circ} \mathbf{C}\right)$} & \multicolumn{2}{|c|}{$\begin{array}{c}\text { Relative } \\
\text { humidity (\%) }\end{array}$} & \multirow[t]{2}{*}{$\begin{array}{c}\text { Rainfall } \\
(\mathrm{mm})\end{array}$} \\
\hline & & $\begin{array}{l}\text { Max. Temp. } \\
\left({ }^{\circ} \mathrm{C}\right)\end{array}$ & $\begin{array}{c}\text { Min. Temp. } \\
\left({ }^{\circ} \mathrm{C}\right)\end{array}$ & $7 \mathrm{am}$ & $2 \mathrm{pm}$ & \\
\hline 27 & 2nd Jul-8th Jul & 26.8 & 16.6 & 86 & 70.6 & 151 \\
\hline 28 & 9th Jul-15th Jul & 27.8 & 20.4 & 87.4 & 70.9 & 49.5 \\
\hline 29 & 16th Jul-22nd Jul & 29.5 & 21.0 & 84.6 & 71.6 & 56.1 \\
\hline 30 & 23rd Jul-29th Jul & 25.9 & 18.0 & 86.9 & 71.1 & 524.6 \\
\hline 31 & 30th Jul-5th Aug & 31.2 & 18.3 & 87.3 & 68.4 & 57.7 \\
\hline 32 & 6th Aug- 12th Aug & 31.1 & 20.4 & 85.6 & 70.4 & 94.3 \\
\hline 33 & $\begin{array}{l}\text { 13th Aug- 19th } \\
\text { Aug }\end{array}$ & 29.5 & 20.7 & 87.7 & 71.1 & 10.5 \\
\hline 34 & $\begin{array}{l}\text { 20th Aug- 26th } \\
\text { Aug }\end{array}$ & 31.5 & 21.6 & 84.4 & 68.6 & 67.3 \\
\hline
\end{tabular}

Table.2 Influence of weather parameters, temperature and relative humidity on the incidence (egg counts and dead hearts formation) of shoot fly in little millet

\begin{tabular}{|c|c|c|c|c|c|c|c|}
\hline \multirow{2}{*}{$\begin{array}{c}\text { Meteorological } \\
\text { week }\end{array}$} & \multicolumn{7}{|c|}{ Weather parameter } \\
\hline & $\begin{array}{l}\text { Max. Temp. } \\
\left({ }^{\circ} \mathrm{C}\right)\end{array}$ & $\begin{array}{c}\text { Mini. } \\
\text { Temp. }\left({ }^{\circ} \mathrm{C}\right)\end{array}$ & $\begin{array}{c}\text { RH } \\
(\%) \\
7 \mathrm{AM}\end{array}$ & $\begin{array}{c}\text { RH } \\
(\%) \\
2 \text { PM }\end{array}$ & $\begin{array}{c}\text { Rainfall } \\
(\mathbf{m m})\end{array}$ & $\begin{array}{c}\text { Eggs /10 } \\
\text { Plants }\end{array}$ & $\begin{array}{c}\text { Dead } \\
\text { heart }(\%)\end{array}$ \\
\hline 27 & 26.8 & 16.6 & 86.0 & 70.6 & 151.0 & $\begin{array}{c}4.5 \\
(2.23) *\end{array}$ & $16.8(24.20)^{* * *}$ \\
\hline 28 & 27.8 & 20.4 & 87.4 & 70.9 & 49.5 & $4.7(2.28)$ & $17.4(24.65)$ \\
\hline 29 & 29.5 & 21.0 & 84.6 & 71.6 & 56.1 & $6.3(2.60)$ & $18.6(25.55)$ \\
\hline 30 & 25.9 & 18.0 & 86.9 & 71.1 & 524.6 & $5.2(2.38)$ & $19.8(26.42)$ \\
\hline 31 & 31.2 & 18.3 & 87.3 & 69.4 & 57.7 & $4.8(2.30)$ & $20.6(26.99)$ \\
\hline 32 & 31.1 & 20.4 & 85.6 & 70.4 & 94.3 & $3.6(2.02)$ & $20.7(27.06)$ \\
\hline 33 & 29.5 & 20.7 & 87.7 & 71.1 & 10.5 & $3.2(1.92)$ & $22.8(28.52)$ \\
\hline 34 & 31.5 & 21.6 & 84.4 & 68.6 & 67.3 & $2.5(1.73)$ & $24.6(29.73)$ \\
\hline
\end{tabular}

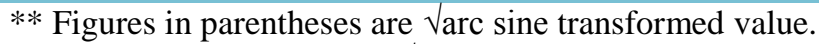

*Figures in parentheses are $\sqrt{ } \mathrm{X}+0.5$ transformed values. 
Table.3 Correlation co-efficient between weather variables and egg/ 10 plants and dead heart percent during Kharif, 2017

\begin{tabular}{|c|c|c|c|c|c|}
\hline \multirow[b]{2}{*}{ Observation } & \multicolumn{5}{|c|}{ Weather parameter } \\
\hline & $\begin{array}{c}\text { Max. } \\
\text { Temp. } \\
\left({ }^{0} \mathrm{C}\right)\end{array}$ & $\begin{array}{c}\text { Mini. } \\
\text { Temp. } \\
\left({ }^{0} \mathrm{C}\right)\end{array}$ & $\begin{array}{c}\text { RH (\%) } \\
7 \mathrm{AM}\end{array}$ & $\begin{array}{c}\text { RH (\%) } \\
2 \text { PM }\end{array}$ & $\begin{array}{c}\text { Rainfall } \\
\text { (mm) }\end{array}$ \\
\hline Eggs/ 10 plants & -0.45634 & -0.33308 & 0.038225 & 0.621393 & 0.295544 \\
\hline Dead heart & 0.649854 & 0.550732 & -0.17913 & -0.58671 & -0.16961 \\
\hline $\begin{array}{l}\text { Significance level } \\
\text { Significant at } 1 \%\end{array}$ & $\begin{array}{l}0.05 \\
\text { Significant }\end{array}$ & $\begin{array}{l}0.01 \\
\%\end{array}$ & & & \\
\hline
\end{tabular}

\section{Per cent dead heart}

The per cent of dead heart varied from 16.86 to 24.66. Maximum infestation of A. pulla was observed in the $3^{\text {rd }}$ week after germination (i.e., $3^{\text {rd }}$ week of July)when the maximum and minimum temperature, $\mathrm{RH}$ at $7 \mathrm{AM}$ and at 2 $\mathrm{PM}$ and rainfall was $29.5,21.0,84.6$ per cent, 71.6 per cent and $56.1 \mathrm{~mm}$, respectively and lowest dead heart was observed at one week after germination. A gradual increase in dead heart was noticed starting from one week of germination Table.1.

The result on correlation studies with weather variables indicated that maximum temperature $(\mathrm{r}=0.649854), \mathrm{RH}$ at $7 \mathrm{AM}(\mathrm{r}=-0.17913)$ and at RH 2 PM ( $\mathrm{r}=-0.58671)$ had negative correlation with dead hearts caused by $A$. pulla. There was decline in dead hearts when the maximum temperature and $\mathrm{RH}$ at $7 \mathrm{AM}$ increased. However, an increase in shoot fly infestation was noticed with the increase in $\mathrm{RH}$ at $2 \mathrm{PM}$. The correlation studies also revealed that apart from these three weather factors, the other weather variables did not influence the dead hearts caused by A. pulla in little millet (Table.2).

In general on rainfed sorghum, the fly activity begins to increase at the onset of the rains coinciding with planting of the crop in June. The population is held at a low level during the preceding dry season due to high temperatures and low humidity and the absence of host plants. As the first crop begins to grow, low populations of flies migrate to it depositing the eggs that produce the following generation. Three to four weeks later a second generation begins to emerge so that later plantings are severely attacked (Clearwater and Othieno.1977) ${ }^{[3]}$. Narayan and Narayan $(1967)^{[13]}$ reported that maximum shootfly damage was on the crop sown during AugustSeptember but the incidence was less on the crop sown during January- February and JuneJuly at Warangal in Andhra Pradesh India. Rao and Rao (1956) ${ }^{[14]}$ suspected that the fly attack is positively correlated to lower temperature as high humidity and also the existence of sorghum crop which is already attacked by the pest.

The maximum egg count per plant observed at three week after emergence ( $3^{\text {rd }}$ week of July). The results obtained revealed that the egg count of the shootfly, Atherigona pulla were significantly and negatively correlated with the maximum temperatures and RH $7 \mathrm{AM}$ and it was significantly and positively correlated with RH at 2 PM. Except for these three factors, there was no influence of other weather parameters on the egg count of A.pulla infesting little millet. The per cent of dead hearts varied from $16.86 \%$ to $24.66 \%$. Maximum infestation of $A$. pulla was 
observed in the $3^{\text {rd }}$ week after germination (i.e. $3^{\text {rd }}$ week of July). There was decline in deadhearts when the maximum temperature and $\mathrm{RH}$ at 7AM increased. However, an increase in shootfly infestation was noticed with the increase in $\mathrm{RH}$ at $2 \mathrm{PM}$.

\section{Acknowledgements}

Authors are thankful to the hon'ble ViceChancellor, the Director of Research and the Dean (Agriculture), Birsa Agricultural University, Kanke, Ranchi for providing facilities, support and moral encouragement for conducting this filed experiment.

\section{References}

Anonymous. Annual progress report All India coordinated Research Project on small millets. Rajendra Agricultural University, Bihar Trihut college of Agriculture, Dholi. In Cooperation with ICAR.1991.

Chorge, B. M and Ramshe, D.G. 1990. Effects of sowing dates on yield attributes, yield, nutrient uptake and protein content of rabi sorghum under irrigations. J.Maharashtra Agric, Univ., 152:142 145.

Clearwater, J. R. and Othieno, S. M. 1977. Population dynamics of Atherigona soccata in the field, in ICIPE Fifth Annual Report Nairobi, pp 14-16.

Dahatonde, B.N. and Moghe P. G. 1991. Performance of rainfed winter sorghum nitrogen under conventional and improved technology in semi - arid tropics. Sorghum Newslett.25:60.

Doharey, K.L., Srivastava, B.G., Jotwani, M.G. and Dang, K. 1977. Effect of temperature and humidity on the development of Atherigona soccata Rondani. Indian J.Ent. 393 :211-215.

FAO, 2011. Food and Agriculture Organization of the United Nations,
Statistical Database internet website: www.fao.org

Hadimani, N. A. and Malleshi, N. G. Studies on Milling, Physico-chemical Properties, Nutrient Composition and Dietary Fibre Content of Millets. Journal of Food Science and Technology (India). 1993;30 (1): 17-20.

Itagi, S. K..Development and evaluation of millet based composite food for diabetics. College of Rural Home Science, U A S Dharwad. 2003;19 (I).

Jotwani M.G..Investigations on insect pests of sorghum and millets with special reference to host plant resistance. Final Technical Report 1972-77. Project A7ENT-1201 Indian Agricultural Research Institute New Delhi. 1978; 114.

Kulkarni, K. A., Bhuti, S. G., Gowda, B. T. S. and Parameshwarappa. Relation between glossyness and plant vigour and shoot fly incidence in sorghum genotypes. Sorghum Newsletter. 1981; 24: 72.

Mahapatra, H.K. and Dhir, B.C. 1994. Effect of Sowing Time on Incidence of Shootfly, Atherigona miliaceae in Little Millet. Indian Journal of Plant protection, 22(1): 9-13.

Marwaha, K.K., Siddiqui, K.H. and Panwar, V.P.S. 1984. Differential reaction of promising maize germplasms to shoot fly species Atherigona soccata Rondani and A.naqvii Steyskal in spring season. J. Ent. Res.121:41-44.

Narayan, K. and Narayan, D. 1967. Observations on the incidence of shootfly. Sorghum Newsl. 10: 37- 38.

Rao, S.B.P. and Rao, D.V.N. 1956a. Studies on the sorghum shoot borer fly Atherigona indica Molloch (Anthomyiidae: Diptera) at Siruguppa. Mysore Agric. J. 31:158-174.

Starks, K.J. 1970. Increasing infestations of the sorghum shootfly in experimental plots. J. econ. Ent. 63(5):1715-1716. 


\section{How to cite this article:}

Kamal Kartik Kenny Kundra, M. K. Chakravarty and Alka Kumari 2020. Influence of Abiotic Factors on THE Shootfly (Atherigona pulla Wiede) Infestation. Int.J.Curr.Microbiol.App.Sci. 9(06): 4037-4043. doi: https://doi.org/10.20546/ijcmas.2020.906.472 